\title{
SIMULTANEOUS PLASMA CLEARANCES OF CREATININE AND CERTAIN ORGANIC COMPOUNDS OF IODINE IN RELATION TO HUMAN KIDNEY FUNCTION ${ }^{1}$
}

\author{
By E. M. LANDIS, K. A. ELSOM, P. A. BOTT and E. H. SHIELS \\ (From the Departments of Pharmacology and of Medicine, University of Pennsylvania, \\ Philadelphia)
}

(Received for publication March 13, 1936)

Creatinine is excreted by the human kidney in higher concentration, relative to plasma level, than any other normal urinary constituent. The exceptionally rapid elimination of certain organic compounds of iodine now used in excretion urography suggested that these substances might be excreted even more rapidly than creatinine. The observations described below compare the plasma clearances of urea, creatinine and organic iodine (skiodan, neoskiodan or diodrast, and hippuran ${ }^{2}$ ) by normal human subjects. Skiodan was cleared from plasma at approximately the same rate as creatinine; neoskiodan and hippuran several times more rapidly than creatinine. Even in the presence of renal disease hippuran clearances were significantly greater than creatinine clearances, without relation to the type of renal lesion.

\section{PROCEDURE}

All subjects omitted breakfast on the day of study and were recumbent during the clearance periods. To a group of $\operatorname{ten}^{3}$ subjects with normal or almost normal kidney function (Table I) water was given in different amounts to produce a wide range of diuresis. To a second group of seventeen patients with renal insufficiency water was given, with two exceptions (Cases 9 and 11, Table II), at the rate of $200 \mathrm{cc}$. hourly from three hours before the beginning of the first clearance period to the end of the last clearance period.

Creatinine was administered orally in doses of

1 The expenses of this investigation were in large part paid by a grant from the Commonwealth Fund.

2 Skiodan, sodium mono-iodo methane sulphonate, contains 52 per cent of iodine. Neoskiodan or diodrast, 3:5 di-iodo-4-pyridon- $\mathrm{N}$-acetic acid diethanolamine, contains 50 per cent iodine. Hippuran, sodium ortho-iodo-hippurate, contains 34.4 per cent iodine, when allowance is made for moisture in the powdered substance.

${ }^{3}$ One subject received neoskiodan and hippuran.
3 or 5 grams in the water given one hour before the beginning of the first clearance period. Skiodan and neoskiodan were given intravenously in doses of $13.0 \mathrm{cc}$. (iodine $2.70 \mathrm{grams}$ ) and $20.0 \mathrm{cc}$. (iodine 3.50 grams) of the respective commercial solutions, approximately fifteen minutes before the beginning of the first clearance period to allow for thorough mixing in the blood stream. Hippuran was administered orally in doses of 12 grams dissolved with the creatinine in the water taken one hour prior to the beginning of the first clearance period.

Urine was collected over two periods, each approximately one hour in duration, and timed to the nearest minute. In order to estimate the percentage of the entire dose eliminated in a given period, the urine formed in the interval between the administration of the organic iodine compound and the beginning of the first period was also saved. Venous blood samples were collected (using lithium oxalate as anti-coagulant) at the beginning and end of each clearance period so that average plasma concentrations of urea, creatinine and iodine could be determined. The blood was centrifuged within ten minutes after it was drawn from the vein to avoid errors arising from diffusion of the organic iodine compound into the erythrocytes while the specimen awaited analysis.

With neoskiodan, the only compound whose properties in this respect were tested in detail, this diffusion is slow since washed human erythrocytes suspended in an isotonic solution of neoskiodan in distilled water were not appreciably hemolyzed after two hours. When neoskiodan was added to whole blood slight loss of iodine from plasma to erythrocytes could be detected by repeated analyses of separated plasma and washed erythrocytes. The change in plasma iodine, corrected for passage of water from cells to serum, 
TABLE I

Plasma clearances of urea, creatinine and iodine (in form of skiodan, neoskiodan and hippuran) in patients with little or no renal insufficiency

\begin{tabular}{|c|c|c|c|c|c|c|c|c|c|c|c|c|c|c|}
\hline \multirow{3}{*}{$\begin{array}{l}\text { Iodine compound } \\
\text { given, dose } \\
\text { and route }\end{array}$} & \multirow{3}{*}{ 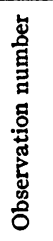 } & \multirow{3}{*}{ 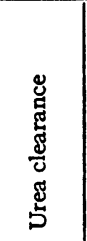 } & \multicolumn{2}{|c|}{ Dosage } & \multicolumn{3}{|c|}{$\begin{array}{l}\text { Average concentration } \\
\text { in plasma }\end{array}$} & \multirow{3}{*}{ 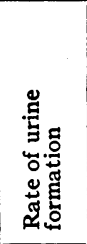 } & \multicolumn{3}{|c|}{ Plasma clearances } & \multirow{3}{*}{ 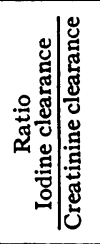 } & \multirow{2}{*}{\multicolumn{2}{|c|}{$\begin{array}{c}\text { Total } \\
\text { organic } \\
\text { iodine } \\
\text { excreted }\end{array}$}} \\
\hline & & & \multirow{2}{*}{ 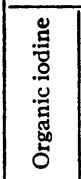 } & \multirow[b]{2}{*}{ 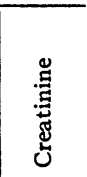 } & & & & & & & & & & \\
\hline & & & & & $\$$ & 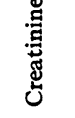 & : & & $\stackrel{\$}{5}$ & 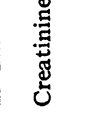 & 晜 & & 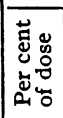 & $\stackrel{\mathscr{H}}{\underline{H}}$ \\
\hline \multirow{3}{*}{$\begin{array}{c}\text { Skiodan } \\
\text { (5.2 grams) } \\
13.0 \mathrm{cc} . \\
\text { intravenously }\end{array}$} & & $\begin{array}{l}\text { per cent } \\
\text { normal }\end{array}$ & grams & grams & $\begin{array}{c}\mathrm{mgm} \\
\text { per } \\
100\end{array}$ & $\begin{array}{c}\text { mgm. } \\
\text { per } \\
100\end{array}$ & $\left|\begin{array}{c}\text { mgm. per } \\
100 \mathrm{cc} .\end{array}\right|$ & $\begin{array}{l}c c \text { per } \\
\text { minute }\end{array}$ & $\begin{array}{c}c c . \\
\text { per } \\
\text { min- }\end{array}$ & $\begin{array}{l}c c \text { per } \\
\text { minute }\end{array}$ & $\begin{array}{l}c c . \\
\text { per } \\
\text { min- }\end{array}$ & & \begin{tabular}{|l} 
per \\
cent
\end{tabular} & 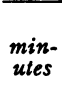 \\
\hline & 1 & $\begin{array}{l}89 \\
86\end{array}$ & 2.70 & 5.0 & $\begin{array}{l}8.7 \\
8.4\end{array}$ & $\begin{array}{l}9.6 \\
7.6\end{array}$ & $\begin{array}{r}15.3 \\
7.1\end{array}$ & $\begin{array}{l}2.0 \\
2.3\end{array}$ & $\begin{array}{l}68 \\
65\end{array}$ & $\begin{array}{l}130 \\
130\end{array}$ & $\begin{array}{l}\text { ule } \\
107 \\
114\end{array}$ & $\begin{array}{l}0.8 \\
0.9\end{array}$ & 59 & 124 \\
\hline & 2 & $\begin{array}{l}70 \\
58\end{array}$ & 2.70 & 5.0 & $\begin{array}{l}15.8 \\
15.3\end{array}$ & $\begin{array}{l}9.5 \\
6.0\end{array}$ & $\begin{array}{r}13.5 \\
7.5\end{array}$ & $\begin{array}{l}2.4 \\
3.5\end{array}$ & $\begin{array}{l}53 \\
43\end{array}$ & $\begin{array}{l}88 \\
86\end{array}$ & $\begin{array}{r}100 \\
83\end{array}$ & $\begin{array}{l}1.1 \\
1.0\end{array}$ & 60 & 151 \\
\hline \multirow{6}{*}{$\begin{array}{c}\text { Neoskiodan } \\
\text { (diodrast) } \\
(7.0 \text { grams) } \\
20.0 \text { cc. } \\
\text { intravenously }\end{array}$} & 3 & $\begin{array}{l}52 \\
49\end{array}$ & 3.50 & 3.0 & $\begin{array}{l}18.4 \\
18.3\end{array}$ & $\begin{array}{l}5.7 \\
5.4\end{array}$ & $\begin{array}{r}12.8 \\
2.5\end{array}$ & $\begin{array}{l}2.0 \\
6.3\end{array}$ & $\begin{array}{l}39 \\
37\end{array}$ & $\begin{array}{l}114 \\
108\end{array}$ & $\begin{array}{l}252 \\
323\end{array}$ & $\begin{array}{l}2.2 \\
3.0\end{array}$ & 70 & 135 \\
\hline & 4 & $\begin{array}{l}109 \\
124\end{array}$ & 3.50 & 3.0 & $\begin{array}{l}17.2 \\
16.2\end{array}$ & $\begin{array}{l}5.7 \\
5.0\end{array}$ & $\begin{array}{l}9.7 \\
1.3 \pm *\end{array}$ & $\begin{array}{r}6.8 \\
11.2\end{array}$ & $\begin{array}{l}82 \\
93\end{array}$ & $\begin{array}{l}136 \\
167\end{array}$ & 327 & 2.4 & 83 & 133 \\
\hline & 5 & $\begin{array}{r}95 \\
109\end{array}$ & 3.50 & 3.0 & $\begin{array}{l}13.2 \\
14.3\end{array}$ & $\begin{array}{l}3.3 \\
2.6\end{array}$ & $\begin{array}{l}6.2 \\
0.9 \pm *\end{array}$ & $\begin{array}{r}14.3 \\
7.5 \\
\end{array}$ & $\begin{array}{l}72 \\
82\end{array}$ & $\begin{array}{l}211 \\
182\end{array}$ & 445 & 2.1 & 87 & 136 \\
\hline & 6 & $\begin{array}{l}64 \\
71\end{array}$ & 3.50 & 3.0 & $\begin{array}{r}10.0 \\
9.7\end{array}$ & $\begin{array}{l}4.1 \\
2.5\end{array}$ & $\begin{array}{l}8.1 \\
1.4 \pm *\end{array}$ & $\begin{array}{l}7.0 \\
7.3\end{array}$ & $\begin{array}{l}48 \\
54\end{array}$ & $\begin{array}{l}108 \\
136\end{array}$ & 291 & 2.7 & 76 & 141 \\
\hline & 7 & $\begin{array}{l}64 \\
73\end{array}$ & 3.50 & 3.0 & $\begin{array}{l}17.6 \\
16.4\end{array}$ & $\begin{array}{l}3.8 \\
3.4\end{array}$ & $\begin{array}{l}6.5 \\
1.0 \pm *\end{array}$ & $\begin{array}{l}1.6 \\
1.5\end{array}$ & $\begin{array}{l}44 \\
47\end{array}$ & $\begin{array}{l}218 \\
210\end{array}$ & 315 & 1.4 & 50 & 144 \\
\hline & 8 & $\begin{array}{l}61 \\
64\end{array}$ & 3.50 & 3.0 & $\begin{array}{l}15.1 \\
14.6\end{array}$ & $\begin{array}{l}3.8 \\
3.3\end{array}$ & $\begin{array}{l}7.7 \\
2.2\end{array}$ & $\begin{array}{l}4.0 \\
2.7\end{array}$ & $\begin{array}{l}46 \\
48\end{array}$ & $\begin{array}{l}207 \\
153\end{array}$ & $\begin{array}{l}522 \\
321\end{array}$ & $\begin{array}{l}2.5 \\
2.1\end{array}$ & 78 & 140 \\
\hline \multirow{3}{*}{$\begin{array}{l}\text { Hippuran } \\
12.0 \text { grams } \\
\text { orally }\end{array}$} & 9 & $\begin{array}{l}95 \\
90\end{array}$ & 4.13 & 5.0 & $\begin{array}{l}15.5 \\
15.3\end{array}$ & $\begin{array}{l}6.7 \\
5.8\end{array}$ & $\begin{array}{l}2.9 \\
1.5\end{array}$ & $\begin{array}{l}2.6 \\
2.7\end{array}$ & $\begin{array}{l}71 \\
68\end{array}$ & $\begin{array}{l}142 \\
164\end{array}$ & $\begin{array}{l}669 \\
476\end{array}$ & $\begin{array}{l}4.7 \\
2.9\end{array}$ & 30 & 177 \\
\hline & 10 & $\begin{array}{l}97 \\
83\end{array}$ & 4.13 & 5.0 & $\begin{array}{l}7.5 \\
7.4\end{array}$ & $\begin{array}{l}6.6 \\
5.6\end{array}$ & $\begin{array}{l}1.5 \\
0.8\end{array}$ & $\begin{array}{l}8.0 \\
4.7\end{array}$ & $\begin{array}{l}73 \\
62\end{array}$ & $\begin{array}{l}134 \\
108\end{array}$ & $\begin{array}{l}486 \\
445\end{array}$ & $\begin{array}{l}3.6 \\
4.1\end{array}$ & 49 & 215 \\
\hline & 11 & $\begin{array}{l}69 \\
60\end{array}$ & 4.13 & 5.0 & $\begin{array}{l}13.3 \\
12.2\end{array}$ & $\begin{array}{l}7.0 \\
5.6\end{array}$ & $\begin{array}{l}1.3 \\
0.7\end{array}$ & $\begin{array}{l}1.7 \\
2.9\end{array}$ & $\begin{array}{l}48 \\
45\end{array}$ & $\begin{array}{l}87 \\
74\end{array}$ & $\begin{array}{l}383 \\
255\end{array}$ & $\begin{array}{l}4.4 \\
3.5\end{array}$ & 24 & 205 \\
\hline
\end{tabular}

* In four cases (Numbers 4 to 7 , inclusive) the plasma iodine of the blood sample taken at the end of the second clearance period was practically zero. Since there was no way of telling at what minute of the period the plasma iodine became zero the average plasma iodine concentration could not be calculated. Clearances were therefore not computed.

amounted to not more than 8 per cent in two hours and to less than 5 per cent in forty minutes.

In studying clearances, separated plasma was used for analyses not only of iodine but also of urea and creatinine. Urea was determined in plasma and urine by the method of Van Slyke and Cullen (1914); creatinine by the method of Folin as described by Holten and Rehberg (1931). Urine and plasma were analyzed for iodine by Leipert's (1933) method with the slight modifications mentioned by Elsom, Bott and Shiels (1936). Skiodan and neoskiodan iodine determinations in plasma were regarded as unreliable if the average plasma iodine concentration was lower than $2.0 \mathrm{mgm}$. per cent. In the work with hippuran a refinement of analytical technique (evaporation of the iodine absorbate to small volume before titration) extended this reliability to $0.5 \mathrm{mgm}$. per cent.

The clearances $(C)$ of both iodine and creatinine were calculated in terms of cc. of plasma cleared per minute by the usual equation: urinary concentration $(U)$ divided by plasma concentration $(B)$ times the volume (in cc.) of urine formed per minute $(V), C=(U \times V) / B$. Urea clearances were calculated both in terms of cc. 
TABLE II

Plasma clearances of urea, creatinine and hippuran iodine in patients with renal disease

\begin{tabular}{|c|c|c|c|c|c|c|c|c|c|c|c|c|c|}
\hline \multirow[b]{2}{*}{ 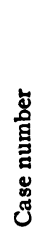 } & \multirow{2}{*}{ Diagnosis } & \multirow{2}{*}{ 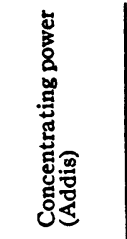 } & \multirow{2}{*}{ 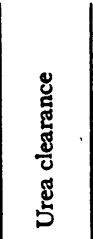 } & \multicolumn{3}{|c|}{$\begin{array}{l}\text { Average concentra- } \\
\text { tion in plasma }\end{array}$} & \multirow[b]{2}{*}{ 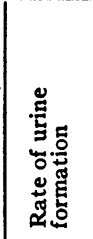 } & \multicolumn{3}{|c|}{ Plasma clearances } & \multirow{2}{*}{ 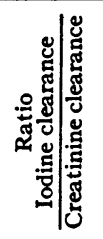 } & \multicolumn{2}{|c|}{$\begin{array}{c}\text { Total } \\
\text { organic } \\
\text { iodine } \\
\text { excreted }\end{array}$} \\
\hline & & & & $\$$ & 苞 & : & & $\$$ & d.ّ. & $\stackrel{\mathscr{g}}{\underline{\Xi}}$ & & 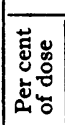 & $\underset{H}{E}$ \\
\hline 1 & Nephrosclerosis, benign & 1.024 & $\begin{array}{c}\text { per cent } \\
\text { normal } \\
\\
88 \\
66\end{array}$ & $\begin{array}{c}\text { mgm. } \\
\text { per } \\
100 \\
c c . \\
9.1 \\
9.0\end{array}$ & $\begin{array}{c}\text { mgm. } \\
\text { per } \\
100 \\
c c . \\
5.5 \\
5.6\end{array}$ & $\begin{array}{c}\mathrm{mgm} . \\
\text { per } \\
100 \\
c c . \\
4.9 \\
3.2\end{array}$ & \begin{tabular}{|c|}
$c c$. per \\
minute \\
\\
5.0 \\
5.8
\end{tabular} & $\begin{array}{c}c c . \\
\text { per } \\
\text { min- } \\
\text { ute } \\
51 \\
49\end{array}$ & $\begin{array}{c}c c . \text { per } \\
\text { minute } \\
94 \\
94 \\
100\end{array}$ & $\begin{array}{c}c c . \\
\text { per } \\
\text { min- } \\
\text { ute } \\
280 \\
259\end{array}$ & $\begin{array}{l}3.0 \\
2.6\end{array}$ & \begin{tabular}{|} 
per \\
cent \\
30
\end{tabular} & $\begin{array}{l}\min \text { mites } \\
183\end{array}$ \\
\hline 2 & Nephrosclerosis, benign & 1.022 & $\begin{array}{l}68 \\
75\end{array}$ & $\begin{array}{l}6.4 \\
6.3\end{array}$ & $\begin{array}{l}4.6 \\
3.4\end{array}$ & $\begin{array}{l}3.8 \\
2.5\end{array}$ & $\begin{array}{l}3.3 \\
7.5\end{array}$ & $\begin{array}{l}51 \\
56\end{array}$ & $\begin{array}{l}112 \\
109\end{array}$ & $\begin{array}{l}234 \\
160\end{array}$ & $\begin{array}{l}2.1 \\
1.5\end{array}$ & 22 & 181 \\
\hline 3 & Nephrosclerosis, benign & 1.019 & $\begin{array}{l}30 \\
27\end{array}$ & $\begin{array}{l}17.6 \\
17.5\end{array} \mid$ & $\begin{array}{l}7.2 \\
7.0\end{array}$ & $\begin{array}{l}4.5 \\
3.1\end{array}$ & $\begin{array}{l}1.0 \\
3.0\end{array}$ & $\begin{array}{l}16 \\
20\end{array}$ & $\begin{array}{l}64 \\
60\end{array}$ & $\begin{array}{l}169 \\
198\end{array}$ & $\begin{array}{l}2.7 \\
3.3\end{array}$ & & \\
\hline 4 & Nephrosclerosis, benign & 1.019 & $\begin{array}{l}56 \\
57\end{array}$ & $\begin{array}{l}12.8 \\
12.5\end{array}$ & $\begin{array}{l}7.3 \\
8.1\end{array}$ & $\begin{array}{l}5.1 \\
4.0\end{array}$ & $\begin{array}{l}1.0 \\
1.6\end{array}$ & $\begin{array}{l}31 \\
40\end{array}$ & $\begin{array}{l}87 \\
89\end{array}$ & $\begin{array}{l}213 \\
215\end{array}$ & $\begin{array}{l}2.5 \\
2.4\end{array}$ & 40 & 180 \\
\hline 5 & Nephrosclerosis, benign & 1.017 & $\begin{array}{l}28 \\
40\end{array}$ & $\begin{array}{l}22.0 \\
22.0\end{array}$ & $\begin{array}{l}11.5 \\
12.0\end{array}$ & $\begin{array}{l}5.0 \\
4.0\end{array}$ & $\begin{array}{l}1.4 \\
3.9\end{array}$ & $\begin{array}{l}18 \\
30\end{array}$ & $\begin{array}{l}31 \\
46\end{array}$ & $\begin{array}{l}118 \\
202\end{array}$ & $\begin{array}{l}3.8 \\
4.4\end{array}$ & 23 & 178 \\
\hline 6 & $\begin{array}{c}\text { Nephrosclerosis, } \\
\text { malignant }\end{array}$ & 1.011 & $\begin{array}{l}13 \\
18 \\
\end{array}$ & $\begin{array}{l}39.1 \\
39.3 \\
\end{array}$ & $\begin{array}{l}12.4 \\
11.9 \\
\end{array}$ & \begin{tabular}{|l|}
5.7 \\
5.2 \\
\end{tabular} & $\begin{array}{l}0.7 \\
1.6 \\
\end{array}$ & $\begin{array}{r}6 \\
12 \\
\end{array}$ & $\begin{array}{r}7 \\
18 \\
\end{array}$ & $\begin{array}{l}14 \\
44 \\
\end{array}$ & $\begin{array}{l}1.8 \\
2.5\end{array}$ & 5 & 187 \\
\hline 7 & $\begin{array}{l}\text { Glomerulonephritis, } \\
\text { subacute, no edema }\end{array}$ & 1.018 & $\begin{array}{l}80 \\
77\end{array}$ & $\begin{array}{l}10.2 \\
10.2\end{array}$ & $\begin{array}{l}4.5 \\
4.3\end{array}$ & $\begin{array}{l}1.3 \\
0.7\end{array}$ & $\begin{array}{l}3.8 \\
3.6\end{array}$ & $\begin{array}{l}60 \\
58\end{array}$ & $\begin{array}{l}106 \\
105\end{array}$ & $\begin{array}{l}368 \\
298\end{array}$ & $\begin{array}{l}3.5 \\
2.8\end{array}$ & 23 & 186 \\
\hline 8 & $\begin{array}{l}\text { Glomerulonephritis, } \\
\text { subacute, no edema }\end{array}$ & 1.018 & $\begin{array}{l}64 \\
62 \\
\end{array}$ & $\begin{array}{l}15.9 \\
15.8 \\
\end{array}$ & $\begin{array}{l}6.5 \\
6.3 \\
\end{array}$ & $\begin{array}{l}3.2 \\
1.9 \\
\end{array}$ & $\begin{array}{l}4.9 \\
5.7 \\
\end{array}$ & $\begin{array}{l}48 \\
47 \\
\end{array}$ & $\begin{array}{r}95 \\
106 \\
\end{array}$ & $\begin{array}{l}313 \\
325 \\
\end{array}$ & $\begin{array}{l}3.3 \\
3.1 \\
\end{array}$ & 37 & 180 \\
\hline 9 & $\begin{array}{l}\text { Glomerulonephritis, } \\
\text { subacute, nephrosis, } \\
\text { no edema }\end{array}$ & 1.031 & $\begin{array}{l}98 \\
78\end{array}$ & $\begin{array}{l}9.0 \\
9.0\end{array}$ & $\begin{array}{l}5.8 \\
4.7\end{array}$ & $\begin{array}{l}0.7 \\
0.7\end{array}$ & $\begin{array}{l}9.7 \\
6.6\end{array}$ & $\begin{array}{l}74 \\
59\end{array}$ & $\begin{array}{l}127 \\
109\end{array}$ & $\begin{array}{l}476 \\
380\end{array}$ & $\begin{array}{l}3.8 \\
3.5\end{array}$ & $\overline{40}$ & 286 \\
\hline 10 & $\begin{array}{l}\text { Glomerulonephritis, } \\
\text { subacute, nephrotic } \\
\text { edema }\end{array}$ & 1.019 & $\begin{array}{l}45 \\
43\end{array}$ & $\begin{array}{l}15.4 \\
15.2\end{array} \mid$ & $\begin{array}{l}6.8 \\
6.2\end{array}$ & $\begin{array}{l}3.1 \\
2.3\end{array}$ & $\begin{array}{l}2.4 \\
2.2\end{array}$ & $\begin{array}{l}34 \\
32\end{array}$ & $\begin{array}{l}87 \\
83\end{array}$ & $\begin{array}{l}272 \\
244\end{array}$ & $\begin{array}{l}3.1 \\
3.0\end{array}$ & 39 & 243 \\
\hline 11 & $\begin{array}{l}\text { Glomerulonephritis, } \\
\text { subacute, nephrotic } \\
\text { edema }\end{array}$ & 1.016 & 34 & 19.4 & 9.9 & 4.6 & 7.5 & 26 & 49 & 304 & 6.2 & 33 & 131 \\
\hline 12 & $\begin{array}{l}\text { Glomerulonephritis, } \\
\text { chronic }\end{array}$ & 1.012 & $\begin{array}{l}10 \\
12 \\
\end{array}$ & $\begin{array}{l}65.8 \\
65.6\end{array}$ & $\begin{array}{r}9.6 \\
10.8 \\
\end{array}$ & $\begin{array}{l}6.6 \\
8.7 \\
\end{array}$ & $\begin{array}{l}0.7 \\
1.4 \\
\end{array}$ & $\begin{array}{l}5 \\
8 \\
\end{array}$ & $\begin{array}{l}10 \\
12 \\
\end{array}$ & $\begin{array}{l}16 \\
19 \\
\end{array}$ & $\begin{array}{l}1.7 \\
1.6\end{array}$ & 6 & 187 \\
\hline 13 & Kidney of pregnancy & 1.029 & $\begin{array}{l}64 \\
65\end{array}$ & $\begin{array}{l}13.5 \\
13.4\end{array}$ & $\begin{array}{l}6.7 \\
6.3\end{array}$ & $\begin{array}{l}2.5 \\
1.9 \\
\end{array}$ & $\begin{array}{l}0.7 \\
2.4\end{array}$ & $\begin{array}{l}28 \\
49\end{array}$ & $\begin{array}{l}65 \\
99\end{array}$ & $\begin{array}{l}327 \\
557 \\
\end{array}$ & $\begin{array}{l}5.0 \\
5.6\end{array}$ & 41 & 181 \\
\hline 14 & Kidney of pregnancy & 1.027 & $\begin{array}{l}71 \\
64\end{array}$ & $\begin{array}{l}12.1 \\
11.7\end{array}$ & $\begin{array}{l}7.7 \\
6.7\end{array}$ & \begin{tabular}{|l|}
3.0 \\
1.4
\end{tabular} & $\begin{array}{l}3.4 \\
1.6\end{array}$ & $\begin{array}{l}54 \\
44\end{array}$ & $\begin{array}{l}159 \\
135\end{array}$ & $\begin{array}{l}313 \\
287\end{array}$ & $\begin{array}{l}2.0 \\
2.1\end{array}$ & 30 & 176 \\
\hline 15 & Kidney of pregnancy & 1.022 & $\begin{array}{l}73 \\
72\end{array}$ & $\begin{array}{l}17.1 \\
17.1\end{array}$ & \begin{tabular}{|r|}
10.0 \\
8.9 \\
\end{tabular} & $\begin{array}{l}2.8 \\
1.5\end{array}$ & $\begin{array}{l}2.6 \\
4.0\end{array}$ & $\begin{array}{l}55 \\
54\end{array}$ & $\begin{array}{l}95 \\
98\end{array}$ & $\begin{array}{l}341 \\
358 \\
\end{array}$ & $\begin{array}{l}3.6 \\
3.7\end{array}$ & 39 & 191 \\
\hline 16 & Pyelonephritis & 1.020 & $\begin{array}{l}65 \\
74\end{array}$ & $\begin{array}{l}12.6 \\
12.5\end{array}$ & $\begin{array}{l}6.7 \\
6.6\end{array}$ & $\begin{array}{l}1.9 \\
1.2\end{array}$ & $\begin{array}{l}2.9 \\
2.9\end{array}$ & $\begin{array}{l}49 \\
56\end{array}$ & $\begin{array}{r}100 \\
98\end{array}$ & \begin{tabular}{|l|}
326 \\
494 \\
\end{tabular} & $\begin{array}{l}3.6 \\
5.0\end{array}$ & 30 & 204 \\
\hline 17 & Diabetes insipidus & $* 1.021+?$ & $\begin{array}{l}69 \\
73\end{array}$ & $\begin{array}{l}7.7 \\
7.9\end{array}$ & $\begin{array}{l}5.9 \\
6.9\end{array}$ & $\begin{array}{l}3.6 \\
2.3\end{array}$ & $\begin{array}{l}6.2 \\
7.5\end{array}$ & $\begin{array}{l}52 \\
55\end{array}$ & $\begin{array}{l}139 \\
135\end{array}$ & $\begin{array}{l}334 \\
377\end{array}$ & $\begin{array}{l}3.6 \\
2.3\end{array}$ & 43 & 180 \\
\hline
\end{tabular}

* Partially controlled with pitressin. 
per minute and in terms of per cent normal, using for the latter the conventional equations of Van Slyke. For the sake of simplicity concentrations of the three iodine compounds were usually recorded in terms of iodine; such notation, of course, does not affect the clearance figures.

\section{OBSERVATIONS}

The excretion of skiodan, neoskiodan and hippuran by patients with little or no renal insufficiency

The plasma clearances of the three organic iodine compounds were compared with simultaneous urea and creatinine clearances in eleven observations on ten subjects whose urea clearances were 49 per cent of normal or more, and whose creatinine clearances were $74 \mathrm{cc}$. per minute or more (Table I).

The intravenous injection of skiodan produced considerable pain in the arm. Therefore doses of only 13.0 cc. were administered and but two patients were studied. With creatinine clearances from 86 to $130 \mathrm{cc}$. per minute in four 1-hour periods skiodan iodine clearances ranged from 83 to $114 \mathrm{cc}$. per minute. The ratio of skiodan iodine clearance to creatinine clearance ranged from 0.82 to 1.14 , averaging 0.95 .

Neoskiodan was administered intravenously in doses of $20 \mathrm{cc}$. (7.0 grams) to six subjects with urea clearances between 49 and 124 per cent of normal. With creatinine clearances between 108

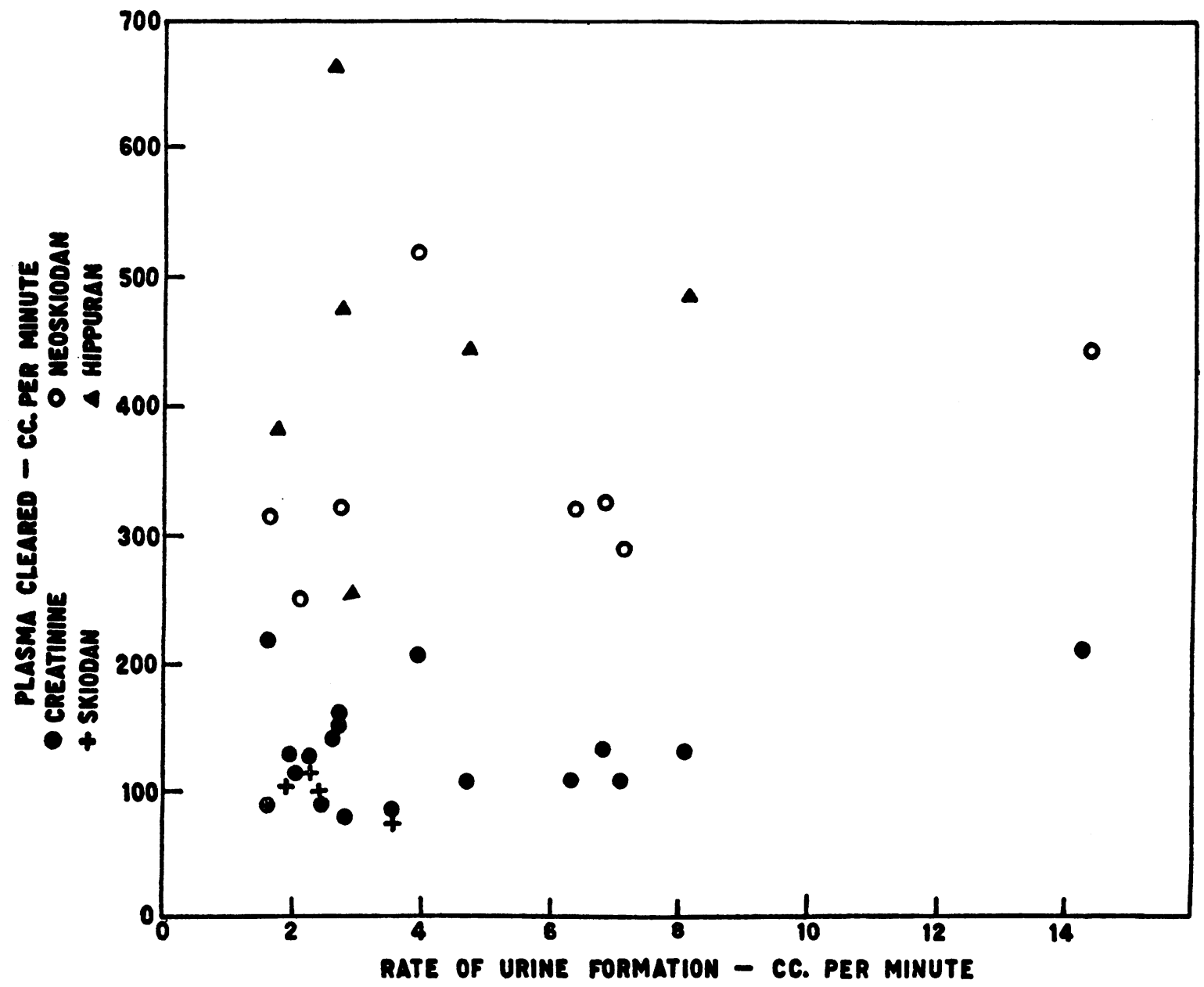

Fig. 1. Showing Clearances of Creatinine (Dots), Skiodan (Crosses), Neoskiodan or Diodrast (Circles) and Hippuran (Triangles) Plotted against Rates of Urine Formation 
and $218 \mathrm{cc}$. per minute neoskiodan iodine clearances ranged from 252 to $522 \mathrm{cc}$. per minute. The ratios of neoskiodan clearance to creatinine clearance varied from 1.44 to 2.99 , averaging 2.31 .

Hippuran was administered in doses of 12.0 grams orally to three subjects with urea clearances of 60 to 97 per cent of normal. With creatinine clearances of 74 to $164 \mathrm{cc}$. per minute hippuran iodine clearances ranged from 255 to 669 cc. per minute. The ratios of hippuran iodine and crea- tinine clearance ranged from 2.90 to 4.71 , averaging 3.87 .

Figure 1 shows that hippuran and neoskiodan clearances were not affected definitely by diuresis ranging from 2 to $14 \mathrm{cc}$. per minute. Owing to the well known diuretic action of these substances very low rates of urine formation were difficult to obtain even when fluids were restricted. This chart shows also that the lowest neoskiodan and hippuran clearances were greater than the highest

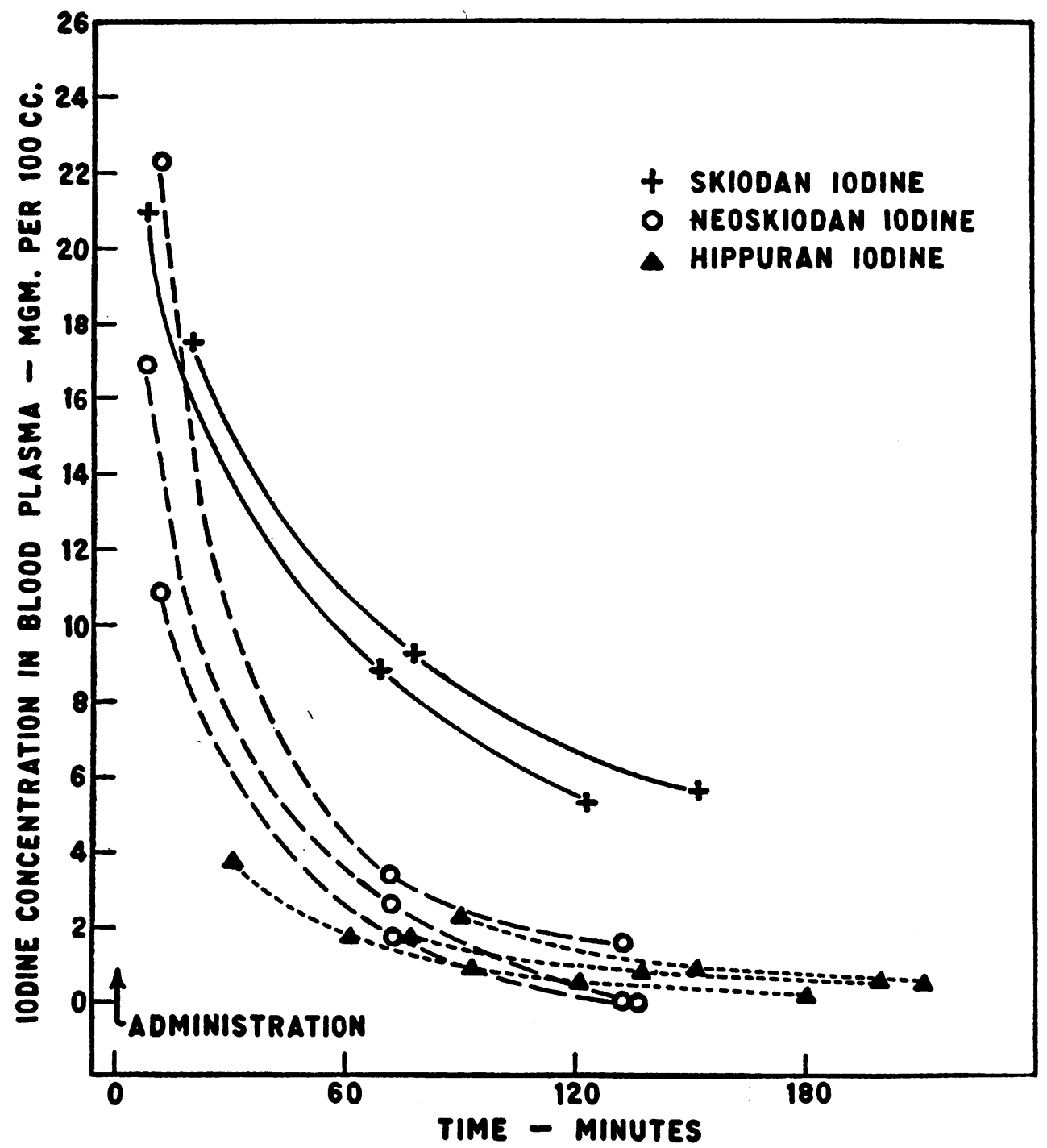

Fig. 2. Showing Characteristic Plasma Iodine Concentrations during Clearance Studies on Skiodan (Crosses), Neoskioman (Circles) and Hippuran (Triangles)

Skiodan and neoskiodan were administered intravenously in doses of 13.0 and $20 \mathrm{cc}$. respectively: Hippuran was given orally in a dose of 12.0 grams. 
creatinine clearances. Skiodan clearances, however, were of the same order of magnitude as were the simultaneous creatinine clearances.

The different efficiency with which neoskiodan and skiodan were excreted is reflected by the change in their plasma concentrations shown in Figure 2. These two substances can be compared since both were introduced intravenously. With approximately equal plasma concentrations at the beginning, the plasma concentration of neoskiodan iodine was conspicuously less than that of skiodan iodine at the end of the first hour. Similarly, as indicated to the right in Table I, approximately 60 per cent of the administered skiodan iodine was eliminated by the end of the second clearance period while, with one excep- tion, 70 per cent or more of neoskiodan iodine was eliminated in approximately the same time.

The plasma concentrations of hippuran and creatinine, after oral administration, are shown in Figure 3 illustrating that hippuran is eliminated far more rapidly than creatinine. In agreement with the clearance figures the changes in plasma concentration (Figures 2 and 3 ) indicate that neoskiodan and hippuran are both excreted far more efficiently than skiodan and creatinine.

Simple calculation reveals that to explain human plasma clearances of 400 to $500 \mathrm{cc}$. per minute through glomerular filtration alone would require an almost impossibly great renal blood flow. Observations in man were necessarily limited to smaller harmless doses so that plasma

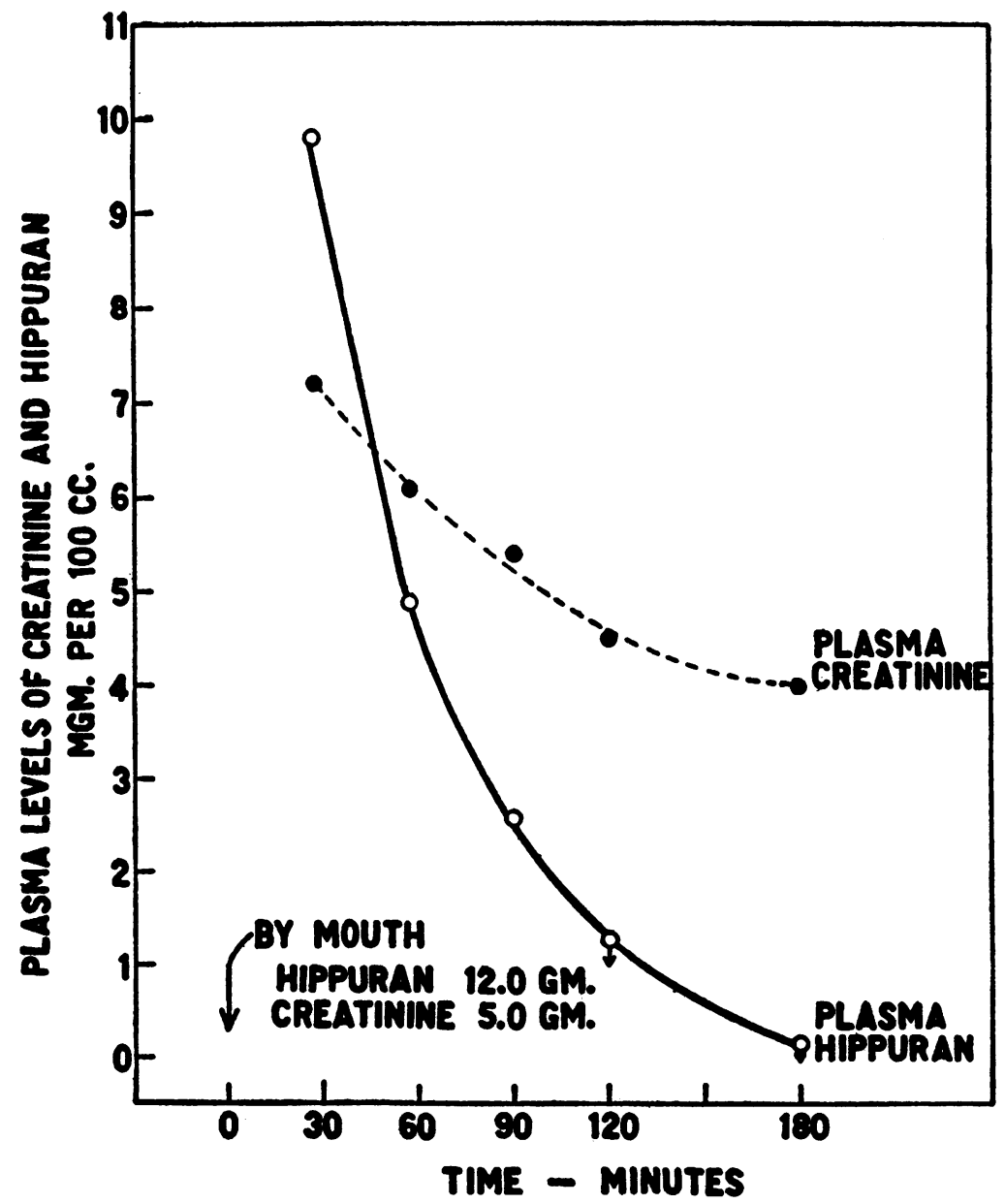

Fig. 3. Showing Concentrations of Hippuran and Creatinine in Plasma after Oral Administration of 12.0 and 5.0 Grams RespectIVELy AT Zero Time 
concentrations of iodine never reached very high levels. In dogs, however, Elsom, Bott and Landis (1934) found that skiodan clearances were approximately equal to creatinine clearances over a much wider range of plasma concentration of iodine (up to $100 \mathrm{mgm}$. per cent). Neoskiodan and hippuran clearances, while several times as great as creatinine clearances at low plasma iodine concentrations, diminished as the doses of neoskiodan and hippuran were increased. When the concentration of neoskiodan or hippuran iodine in plasma was $70 \mathrm{mgm}$. per cent or more, their clearances were of the same order of magnitude as creatinine clearances. It was inferred therefore that the high clearances of these two substances at low plasma concentrations must be due to tubular activity. More recent evidence has supported this inference (Elsom et al. (1936)).

Plasma clearances of creatinine and hippuran in patients with renal disease

Hippuran was administered to patients with renal disease in order to determine whether a measurable dissociation of glomerular and tubular dysfunction could be detected by comparing hippuran and creatinine clearances. Table II presents data on seventeen cases, grouped primarily according to clinical diagnosis and secondarily in each category according to severity of renal involvement, as measured by a concentration test.

In the course of clinical study quantitative studies of urinary sediment were done, using 12hour samples of urine collected during complete restriction of fluids for 24 hours (Addis (1925)). In no instance was there any conspicuous diuresis in progress so that even though edema was present (in 2 cases) the restriction in concentrating power agrees in general with diminution in urea and creatinine clearances except in one patient with diabetes insipidus. Urea clearances were determined in the two 1-hour periods with moderate diuresis and also for the 12-hour dehydration period when urine flow was less than $1.0 \mathrm{cc}$. per minute. For this purpose the 12-hour concentrated urine and a single blood sample taken at the end of the urine collection were analyzed for urea nitrogen, the standard urea clearance being calculated according to the usual equation.
Renal abnormality was ascribed to vascular disease in six cases, to glomerulonephritis in twelve, to pregnancy in three, to pyelonephritis in one and to diabetes insipidus in one. In the first eight cases there was little reason to believe that tubular and glomerular involvement were disproportionate. The remaining nine presented clinical pictures apt to be associated with preponderant abnormality of tubular function and/or structure. It was our purpose primarily to determine whether these two groups excreted hippuran with different efficiency relative to creatinine.

Table II shows, in general, that in each case, irrespective of type or severity of renal damage, hippuran was cleared from the blood plasma from one and one-half to six times more rapidly than creatinine. The total organic iodine excreted in approximately three hours following administration varied considerably. A patient with diabetes insipidus excreted the greatest amount (43.2 per cent) while two patients with isosthenuria excreted 5.4 and 6.1 per cent in the same time. The total elimination showed no constant deviation with small changes in creatinine clearance or concentrating power. It seems doubtful whether studies of total output of organic iodine compounds can be used to detect mild grades of renal insufficiency.

The hippuran iodine clearances (Table II) ranged from $13.5 \mathrm{cc}$. per minute in a patient with isosthenuria and azotemia to $557 \mathrm{cc}$. per minute in a patient able to excrete urine with a specific gravity of 1.029. The hippuran iodine clearances were, however, always greater than the corresponding creatinine clearances even when isosthenuria had developed. The relation between the clearances of hippuran iodine and creatinine is shown in Figure 4. The points are distributed approximately about a straight line indicating that with diminishing renal function the creatinine and hippuran iodine clearances are reduced roughly in proportion. The symbols representing the diagnosis in each instance are distributed in a haphazard manner; the points do not group themselves according to diagnosis. It appears therefore that renal insufficiency diminishes the clearances of hippuran iodine and creatinine proportionately, irrespective of the pathology pro- 


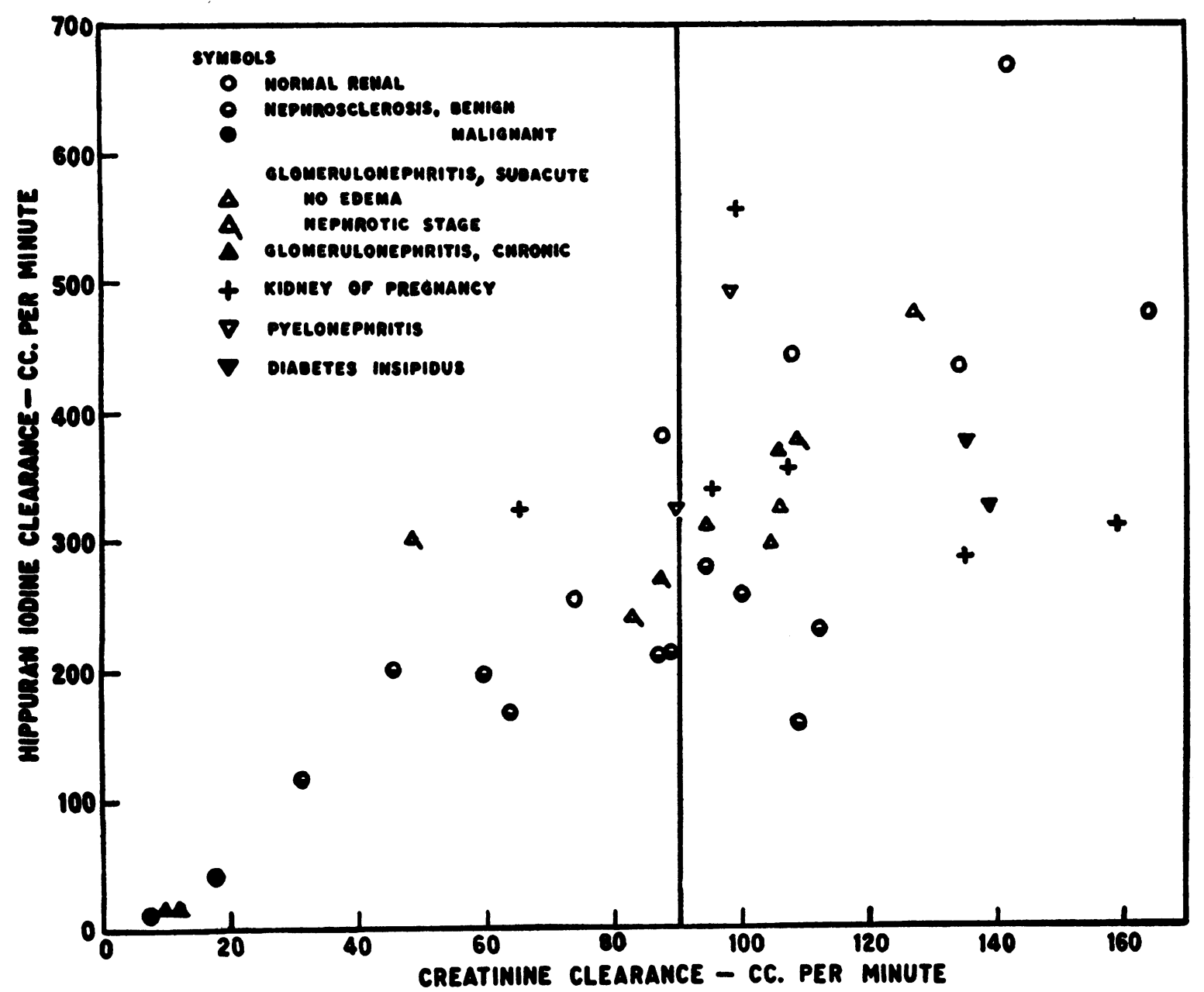

Fig. 4. Hippuran Iodine Clearances Plotted against Simultaneous Creatinine Clearances Symbols indicating diagnoses are given in the upper left hand corner.

ducing the insufficiency. If low normal creatinine clearance be taken as $90 \mathrm{cc}$. per minute hippuran iodine clearances corresponding to normal creatinine clearances range from 160 to $669 \mathrm{cc}$. per minute. In this group the lowest iodine clearance of $160 \mathrm{cc}$. per minute was associated with a creatinine clearance of $109 \mathrm{cc}$. per minute. $\mathrm{Pa}$ tients with nephrosis presented no special deficiency in hippuran excretion.

When hippuran iodine clearances are compared to urea clearances (Figure 5) it is evident that the efficiency with which these two substances are eliminated is likewise reduced proportionately without differences ascribable to the condition producing the reduction in kidney function. If 70 per cent be taken as the lowest normal urea clearance the hippuran iodine clearances corresponding to normal urea clearance range from 160 to $669 \mathrm{cc}$. per minute, in complete agreement with the distribution in Figure 4 for creatinine and hippuran clearances.

Hippuran iodine clearances are compared in Figure 6 with the specific gravity of the $u$. ine observed in each case during a concentration regime. If a urinary specific gravity of 1.025 be taken as low normal under the conditions imposed, the hippuran iodine clearances in the group designated as normal ranged from 255 to $669 \mathrm{cc}$. per minute. As in the preceding charts the symbols representing different diagnoses are not segregated so that apparently diminution in hippuran clearance is more closely asso- 


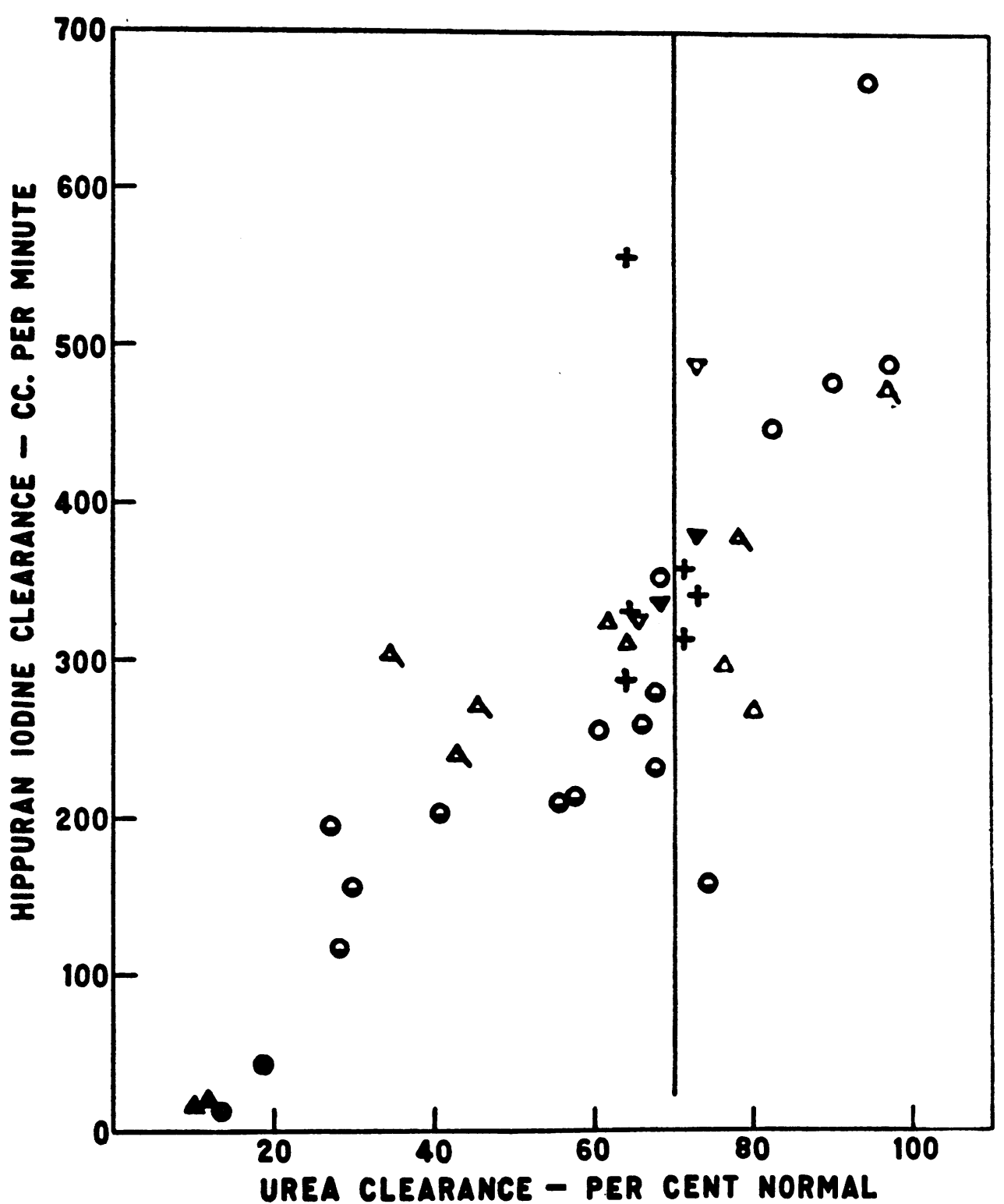

Fig. 5. Hippuran Iodine Clearances Plotted against Simultaneous Urea Clearances. Symbols as in Figure 4

ciated with restricted concentrating power than with the specific pathology which has produced the renal insufficiency.

Hippuran iodine clearance

The ratio, Creatinine clearance

differ significantly in the various clinical conditions producing renal dysfunction. A ratio of 1.0 would indicate that creatinine and hippuran iodine were cleared at the same rate, while a ratio of 2.0 or 3.0 indicates that hippuran was removed from the plasma two or three times as efficiently as creatinine. When grouped according to diagnosis these ratios vary widely but are all significantly greater than 1.0 , the lowest being 1.47. Ratios found in conditions that are primarily vascular do not differ from those found in conditions that are primarily renal. It is possible, however, that advanced renal damage and isosthenuria lead to progressive reduction in the 


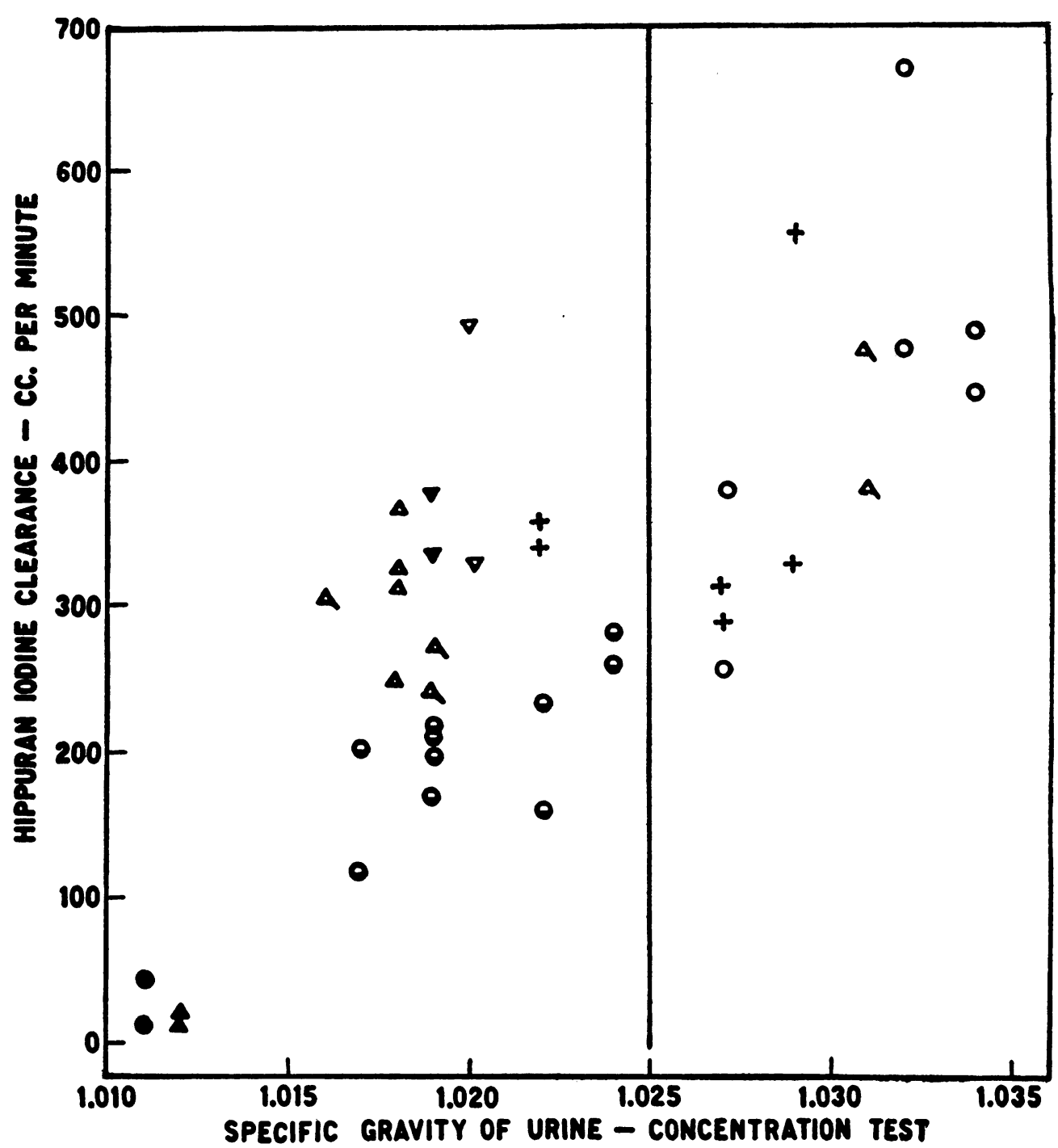

Fig. 6. Hippuran Iodine Clearances Plotted against Concentrating Power Exhibited by each Patient. Symbols as in Figure 4

power of the kidney to clear the plasma of hippuran more rapidly than creatinine.

\section{DISCUSSION}

Recent studies of renal physiology (Richards et al. (1929) et seq.) have massed impressive evidence showing that, in the amphibian, urine is formed through primary ultrafiltration of plasma in the glomeruli, followed by secondary elaboration of this filtrate in the tubules. These studies lead logically to the hope of separating, at least qualitatively, glomerular and tubular components in certain clinical types of renal dysfunction.
Early attempts by Rehberg (1926) to measure glomerular filtrate in man were based on a first assumption that the concentration of creatinine was the same in plasma and glomerular filtrate. This assumption was later proved correct for the amphibian by Bordley, Hendrix and Richards (1933). Second, Rehberg (1926) further assumed that as the glomerular filtrate passed through the tubules creatinine was neither added to, nor lost from, the original glomerular filtrate however much this filtrate might be modified by the reabsorption of water and solutes other than creatinine. The discovery of several substances 
which are chemically different from creatinine, but nevertheless are cleared at the same rate as creatinine, would strengthen this second assumption considerably. Richards, Westfall and Bott (1934), and Shannon and Smith (1935) found in dogs that inulin and creatinine were, in fact, cleared from plasma at the same rate. It is interesting to note that in man the clearances of skiodan and creatinine appeared to have the same order of magnitude; however, a larger number of determinations must be performed before it can be concluded that human skiodan and creatinine clearances are identical.

Shannon (1935) observed, however, in normal human subjects that when plasma creatinine is low creatinine clearances are slightly, but definitely, greater than simultaneous inulin clearances. $\mathrm{He}$ presented evidence that the human kidney differs from the dog's kidney in that the former appears to eliminate exogenous creatinine partly by tubular secretion. It would therefore be unjustifiable at the present time to assume that creatinine clearance in man is a quantitative measure of the rate of glomerular filtration. It is almost certain, however, that clearances conspicuously greater than those of creatinine must involve tubular activity in addition to glomerular filtration.

Marshall (1931) concluded on this basis that the dog's kidney must eliminate phenol red through tubular secretion. Sheehan and Southworth (1934) state that in anesthetized rabbits filtration alone failed to account wholly for phenol red elimination. By similar reasoning it appears that the human kidney excretes neoskiodan and hippuran partly through tubular secretion. Herbst and Baumrucker (1934) found that neoskiodan and phenolsulfonephthalein when injected intravenously in the same subjects at different times were eliminated at similar, but not identical, rates. In dogs the simultaneous injection of neoskiodan and phenolsulfonephthalein reduced the rapidity with which the latter appeared in the urine. Marshall (1931) calculated that in dogs glomerular filtration accounts for 10 to 17 per cent of phenol red elimination. Our own data indicate that glomerular filtration accounts for 33 to 70 per cent of neoskiodan elimination and for 21 to 34 per cent of hippuran elimination.

Uroselectan has been identified in the glomerular filtrate of frogs after intravenous injection
(Hughes and Peterfi (1931)), and there is no reason to believe that the physical filtrability of the other urographic iodine compounds differs from that of uroselectan. It is far more likely that differences in the rate of excretion depend upon the degree of tubular activity involved. Binz and Maier-Bode (1932) reported that straight chain iodine compounds were eliminated more slowly than a series of iodine compounds containing the benzene ring. Skiodan, the clearances of which were similar to those of creatinine, is a straight chain compound while neoskiodan and hippuran, which are ring compounds, are excreted with plasma clearances several times greater than those of creatinine.

Lichtenberg and Swick (1929) suggested tentatively that the organic compounds of iodine might be of service in estimating kidney function, but artefacts, which make it dangerous to estimate renal function from the intensity of the radiographic shadows produced during intravenous urography, have been emphasized repeatedly (Lichtenberg and Swick (1929); Heckenbach (1930) ; Lichtenberg (1931) ; Lindenfeld (1932); Lauber (1932); Olivet (1933); Chabanier and Lobo-Onell (1933); Hefke (1934)). It is generally agreed also that renal insufficiency prevents good radiographic visualization of the urinary tract by means of intravenous urography (Heritage (1930) ; Jezler (1931); Lichtenberg (1931); Pask (1933), etc.). This clinical observation is explained by the conspicuously diminished iodine clearances in renal insufficiency.

Kidney function has been estimated by studying the percentage of the dose of organic iodine which is excreted in a given time (Heckenbach (1930) ; Yago (1931) ; Olivet (1931) ; Cuthbertson and Jacobs (1932); Lindenfeld (1932) or the specific gravity of the urine after the injection of organic iodine compounds (Heckenbach (1930); Heritage and Ward (1930); Takahashi et al. (1931) ; Mardersteig (1931 a, b)). Such determinations are subject to error from possible storage in the general body tissues (Olivet (1931) ; Damm and Junkmann (1932); Lengemann (1934)) or from variations in the amount of water available for excreting the iodine containing compounds (Heckenbach (1930); Cuthbertson and Jacobs (1932); Damm and Junkmann (1932)). According to our data also, 
studies of this type are not likely to detect minor grades of renal insufficiency.

The studies of hippuran clearance in patients with renal conditions were designed to test the possibility of differentiating glomerular and tubular involvement in renal disease. There was no evidence that hippuran clearances provided more information than that obtainable through urea clearances, creatinine clearances or concentration tests. The elimination of hippuran appears to be conditioned by general renal function rather than by specific glomerular or tubular dysfunction. Hippuran clearances, therefore, while of considerable physiological interest, present no clinical advantages to compensate for the greater labor of the analyses involved.

\section{SUMMARY}

The clearances of three organic compounds of iodine were compared with simultaneous creatinine clearances. In normal subjects skiodan and creatinine clearances were of the same order of magnitude.

Neoskiodan and hippuran clearances were significantly greater than creatinine clearances; the differences were so conspicuous that the elimination of these two iodine compounds can not be explained by simple glomerular filtration, but must be ascribed in part to tubular activity.

In renal insufficiency hippuran clearances were in general reduced proportionately to urea clearances, creatinine clearances and concentrating power. Hippuran clearances were related more closely to the grade of renal insufficiency as a whole than to preponderance of glomerular or tubular dysfunction; they remained greater than creatinine clearances even in advanced renal failure.

The plasma clearances of these organic compounds of iodine, while of considerable physiological interest, provide no special information to recommend their use in the diagnosis or clinical study of renal disease.

\section{BIBLIOGRAPHY}

Addis, T., A clinical classification of Bright's diseases. J. A. M. A., 1925, 85, 163.

Binz, A., and Maier-Bode, $H$., Utber die Harnfähigkeit organischer Halogenverbindungen. Biochem. Ztschr., 1932, 252, 16.
Bordley, J., III, Hendrix, J. P., and Richards, A. N., Quantitative studies of the composition of glomerular urine. XI. The concentration of creatinine in glomerular urine from frogs determined by an ultramicroadaptation of the Folin method. J. Biol. Chem., 1933, 101, 255.

Chabanier, H., and Lobo-Onell, C., Urographie d'élimination et exploration fonctionnelle comparée des reins. Presse méd., 1933, 41, 2010.

Cuthbertson, D. P., and Jacobs, A., Intravenous urography; preliminary observations on the recovery of iodine as a test of renal function following the injection of uroselectan. Brit. J. Urol., 1932, 4, 36.

Damm, E., and Junkmann, K., Studien über die Ausscheidung von Nierenkontrastmitteln. Klin. Wchnschr., 1932, 11, 2032.

Elsom, K. A., Bott, P. A., and Landis, E. M., Simultaneous excretion of creatinine and certain organic compounds of iodine. Proc. Soc. exper. Biol. and Med., 1934, 32, 77.

Elsom, K. A., Bott, P. A., and Shiels, E. H., On the excretion of skiodan, diodrast and hippuran by the dog. Am. J. Physiol., 1936, 115, 548.

Hefke, H. W., Limitations of intravenous urography. Wisconsin M. J., 1934, 33, 742.

Heckenbach, W., Funktionsuntersuchungen bei der Ausscheidung des Uroselectans. Klin. Wchnschr., 1930, 9, 684.

Herbst, R. H., and Baumrucker, G. O., A new colorimetric test for renal function using intravenous iodine preparations. J. Urol., 1934, 32, 131.

Heritage, K., and Ward, R. O., Excretion urography; a preliminary note on a new method of radiological demonstration of the urinary tract. Brit. M. J., 1930, $1,734$.

Heritage, K., Intravenous pyelography as a test of renal function. Lancet, 1930 2, 132.

Holten, C., and Rehberg, P. B., Studies on pathological function of kidneys in renal disease, especially Bright's disease. Acta med. Scandinav., 1931, 74, 479.

Hughes, B., and Peterfi, T., Der Nachweis von Uroselektan im Glomerulus der Froschniere. Ztschr. f. urol. Chir., 1931, 31, 146.

Jezler, A., Zur Uroselektanpyelographie. Mit Angabe einer einfachen ausführbaren chemischen Funktionsprüfung. Schweiz. med. Wchnschr., 1931, 61, 355.

Lauber, H. J., Die intravenöse Pyelographie und ihre Beziehung zur Nierenfunktion. Beitr. z. klin. Chir., 1932, 155, 146.

Leipert, T., Die Bestimmung kleinster Jodmengen in organischem material. Biochem. Ztschr., 1933, 261, 436.

Lengemann, W., Histohämorenale Verteilungsstudien mit Pelviren und Perabrodil beim normalen und nierenexstirpierten Hund. Ztschr. f. d. ges. exper. Med., 1934, 92, 675.

von Lichtenberg, A., and Swick, M., Klinische Prüfung des Uroselectans. Klin. Wchnschr., 1929, 8, 2089. 
von Lichtenberg, A., Principles and new advances in excretion urography. Brit. J. Urol., 1931, 3, 119.

Lindenfeld, L., Auswertung der intravenöesen Pyelographie als Funktionsprüfung mit besonderer Berücksichtigung der Jodausscheidung nach Abrodil-injektionen. Ztschr. f. Urol., 1932, 26, 364.

Mardersteig, K., Nierenfunktionsprüfung bei intravenöser Pyelographie mit Uroselectan. Deutsches Arch. f. klin. Med., 1931, 171, 78.

Mardersteig, K., Nierenfunktionsprüfung bei intravenöser Pyelographie mit Abrodil. Deutsches Arch. f. klin. Med., 1931, 171, 629.

Marshall, E. K., Jr., The secretion of phenol red by the mammalian kidney. Am. J. Physiol., 1931, 99, 77.

Olivet, J., Abrodilausscheidung bei gesunden und kranken Nieren. Klin. Wchnschr., 1931, 10, 1760.

Olivet, J., Jodverteilung nach Injektion von Abrodil. II. Klin. Wchnschr., 1931, 10, 2396.

Olivet, J., Ist die intravenöse Pyelographie eine Funktionsprüfung bei inneren Nierenkrankungen? Ztschr. f. klin. Med., 1933, 125, 9.

Pask, E. H. A., Intravenous urography in diagnosis of tuberculosis of kidney. Brit. J. Tuberc., 1933, 27, 112.

Rehberg, P. B., Studies on kidney function. I. The rate of filtration and reabsorption in the human kidney. Biochem. J., 1926, 20, 447.

Rehberg, P. B., Studies on kidney function. II. The excretion of urea and chlorine analysed according to a modified filtration-reabsorption theory. Biochem. J., 1926, 20, 461.

Richards, A. N., Methods and Results of Direct Investigations of the Function of the Kidney. Williams \& Wilkins Co., Baltimore, 1929.

Richards, A. N., Westfall, B. B., and Bott, P. A., Renal excretion of inulin, creatinine and xylose in normal dogs. Proc. Soc. Exper. Biol. and Med., 1934, 32, 73.

Shannon, J. A., and Smith, H. W., The excretion of inulin, xylose and urea by normal and phlorizinized man. J. Clin. Invest., 1935, 14, 393.

Shannon, J. A., The renal excretion of creatinine in man. J. Clin. Invest., 1935, 14, 403.

Sheehan, H. L., and Southworth, H., The renal elimination of phenol red. J. Physiol., 1934, 82, 438.

Takahashi, A., Tsuchiya, F., and Ishizu, S., Intravenöse pyelographie; die Nierenfunktionsprüfung durch Abrodilausscheidung und das Problem der Nierenreizung (Röntgenologische Nierenfunktionsprüfung durch Belastungsverfahren mittelst Abrodil). Jap. J. Dermat. and Urol., 1931, 31, 26.

Van Slyke, D. D., and Cullen, G. E., A permanent preparation of urease, and its use in the determination of urea. J. Biol. Chem., 1914, 19, 211.

Yago, K., Úber die Ausscheidung des Uroselectans als Probe der Nierenfunktion bei intravenöser Pyelographie. Tohoku J. Exper. Med., 1931, 18, 284. 